\title{
Mathematics E-LKPD With Project-Based Learning and HOTS Activities
}

\section{Desi Susiana1, Ndara Tanggu Rendra ${ }^{2}$}

1,2 Universitas Pendidikan Ganesha, Singaraja, Indonesia

\section{A R T I C L E I N F O}

Article history:

Received March 08, 2021

Revised March 11, 2021

Accepted April 30, 2021

Available online May 25, 2021

Kata Kunci:

E-LKPD, Project Based

Learning, HOTS

Keywords:

E-LKPD, Project Based

Learning, HOTS

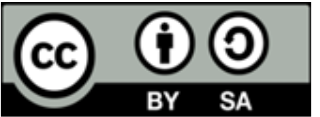

This is an open access article under the CC BY-SA license.

Copyright (C) 2021 by Author. Published by Universitas Pendidikan Ganesh

\begin{abstract}
ABSTRAK
Penelitian pengembangan ini dilakukan berdasarkan hasil analisis kebutuhan media pembelajaran yang ada di Sekolah Dasar. Guru masih menggunakan media konvensional dalam menyampaikan materi terutama dalam pembelajaran matematika. Oleh sebab itu, perlu dilakukan pengembangan media yang mampu menarik perhatian peserta didik serta media yang praktis digunakan oleh guru maupun peserta didik. Media yang dapat dikembangkan berupa E-LKPD berbasis project based learning dengan aktivitas HOTS pada materi volume kubus dan balok yang diuji validitasnya. Penelitian ini mengacu pada pengembangan 4-D. Pada penelitian ini tahap penyebaran tidak dilaksanakan karena saat ini masih dalam masa pandemi Covid-19. Subjek penelitian ini adalah E-LKPD pada pembelajaran matematika materi volume kubus dan balok. Objek penelitian ini adalah dua orang dosen ahli isi materi matematika, dua orang dosen ahli media pembelajaran, dan dua praktisi. Pengumpulan data dalam penelitian ini menggunakan metode kuesioner. Untuk mengetahui validitas media $E$ LKPD, digunakan instrumen rating scale berupa lembar penilaian yang diberikan kepada beberapa ahli. Berdasarkan hasil analisis validitas produk yang dilakukan oleh ahli materi, ahli media dan praktisi adalah $85 \%$ dengan kulifikasi baik oleh ahli isi materi matematika, 89,29\% dengan kualifikasi baik oleh ahli media pembelajaran dan $87,5 \%$ dengan kualifikasi baik oleh praktisi. Sehingga dapat dikatakan bahwa media E-LKPD pada mata pelajaran matematika materi volume kubus dan balok dinyatakan valid dan memiliki kualifikasi baik.
\end{abstract}

A B S T R A C T

Less attractive learning media causes low interest in student learning. So, the need for concrete learning media following the stages of student development. This study aimed to create a valid and practical demonstration-based learning video on changing objects in the fifth grade of elementary school. This research is development research using the 4D model. The subjects of this study were two material experts, two media experts, two practitioners, and five students. The method used in data collection in this study is the rating scale method with an instrument in the form of a rating scale ranging from 1-4. The data obtained were analyzed by calculating the validity index of expert judgment and calculating the average response of practitioners and students. The analysis results showed that the material expert's validity index obtained the lowest score of 0.84 and the highest score was 1 with the very good category. The media expert validity index got the lowest score of 0.67 in the good category, and the highest score was 1 , which is in the very good category. The overall average score of the practitioner's response was 3.82, and the student response was 3.78, which was in the very good category. Based on the results of this analysis, demonstration-based instructional video media on the topic of changing objects in fifth-grade elementary schools were declared good and suitable for use in the learning process.

\section{INTRODUCTION}

Mathematics is known for its theoretical knowledge, full of symbols and formulas. Mathematics is also known to be a difficult subject for some students. Mathematics is one of the most difficult and scary subjects for some students (Kamarullah, 2017; Pansa, 2017). It is because mathematics is related to numbers, formulas, and arithmetic. Mathematics lessons have not been able to improve a good understanding of mathematics for students. In addition, students do not understand the important role of 
mathematics itself, so mathematics is considered a boring and scary subject (Dwiranata et al., 2019; Suartama, 2010). It causes students to have difficulty in solving problems in mathematics. Problemsolving in mathematics is an important factor because problem-solving is a basic skill that students must master. This difficulty can also be caused by the learning media used by the teacher. One of the students' difficulties understanding mathematics material is the learning media (Amir, 2014; Zakiy et al., 2018). Such as problems in learning activities that always use conventional methods and are supported by textbooks. In addition, the use of methods that are less varied and the lack of use of learning media can allegedly cause the mathematics learning process to seem monotonous and less creative (Al Farisyi et al., 2016; Masykur et al., 2017). For this reason, it is necessary to develop learning media that is following the times and according to the needs of students. Media plays a very important role in improving the quality of learning (Purnama et al., 2017; Tafonao, 2018). Media can be used to build understanding and mastery of abstract mathematical concepts and symbols into concrete.

The importance of learning mathematics cannot be separated from its usefulness in every aspect of life. Some mathematics is used in several fields: health, economics, technology, physics, education, and other aspects. Mathematics lessons need to be given to all students in elementary schools to equip students with the ability to think logically, analytically, systematically, critically, and creatively and work together (Indaryati \& Jailani, 2015; Saefudin, 2012). Studying mathematics subjects can instill the habit of reasoning in one's thinking activities. Mathematics can also improve the mindset of students. In mathematics, a student will learn about counting and is expected to apply it in everyday life. Elementary school students can understand mathematical concepts if they are presented in concrete and diverse forms. Effective mathematics learning can mostly be done through guided discovery, meaningful application, and problem-solving. Through these three things, mathematics learning becomes more meaningful.

Mathematics is still said to be difficult by some students. Mathematics learning still emphasizes memorizing formulas quickly, resulting in the lack of training in students' high-level thinking skills (Handayani, 2017; Widyastuti \& Pujiastuti, 2014). In addition, teachers only use learning tools that are already available, so students need a long time to understand the subject matter. Mathematics learning activities in elementary schools tend to be teacher centers. Students are asked to listen to the explanations presented by the teacher, followed by doing exercises and discussing classical exercises again (Puspita \& Dewi, 2021). Most teachers have not been able to make E-LKPD media independently. Many teachers have difficulty developing LKPD. Most teachers only rely on textbooks to become bored and passive. In addition to these problems, some problems were found after distributing questionnaires to fifth-grade teachers of SD Gugus IV, Kecamatan Buleleng. Teachers have not innovated in developing media or teaching materials when students learn from school or learn from home. The results of the questionnaire analysis stated that (1) $57 \%$ of teachers did not use learning media, especially in learning mathematics, (2) $100 \%$ of teachers stated that in learning mathematics teachers did not use media in the form of E-LKPD, (3) 100\% of teachers stated that E-LKPD media in mathematics learning needs to be developed.

Based on this, one of the learning media that can be used in learning mathematics is E-LKPD. Researchers know that many mathematics materials need to be taught with learning media, especially in learning mathematics. The material is in the form of volumes of cubes and blocks for fifth-grade elementary school. The use of teaching materials that only use student books in the learning process is also one reason for the importance of developing media in E-LKPD in learning mathematics for fifth-grade elementary school volume cubes and blocks. Based on these problems, the thing that can be done is media development. Learning media is the most important element in the learning process (Muhson, 2010; Nurita, 2019). The benefit of this learning media is that it provides guidelines for teachers to achieve learning objectives to explain learning materials in a systematic order and present interesting material to improve the quality of learning. In addition, the media can also increase students' motivation and interest in learning so that students can think and analyze the subject matter given by the teacher properly with a pleasant learning situation, and students can understand the subject matter easily. One of the media that can be developed is E-LKPD. E-LKPD was chosen as a solution due to the times that have begun to take advantage of technology. The development of this E-LKPD needs to be done so that the learning process can be more meaningful.

In connection with this, it is necessary to conduct research on the development of E-LKPD, which will make students active, creative, and independent in learning mathematics so that students are no longer afraid of learning mathematics. This condition is ini line awith research which states that E-LKPD is feasible (effective) to be used in the learning process (Khotimah, 2020). Other relevant research can also. The results of this study state that students practically use the electronic LKPD. This study indicates that the E-LKPD is feasible (effective) to be used at the elementary level (Ulfa et al., 2020). In connection with the development of the E-LKPD developed in this study, it has differences with other studies. The 
difference is in the material taken, the volume of cubes and blocks. In addition, the material in the E-LKPD is packaged with a project-based learning model with HOTS activities. So the purpose of this study is to develop an E-LKPD based on project-based learning with HOTS activities on the volume of cubes and blocks. With the development of the E-LKPD, it is hoped that teachers can be helped in teaching and learning activities in the classroom to play an active role in learning mathematics to improve the quality and results in learning.

This development certainly requires an attractive learning model so that students are more motivated to learn. One model that can be applied in the development of E-LKPD is project-based learning. The project-based learning model is a learning model that focuses on product creation by involving students directly. This model can increase students' motivation to learn mathematics (Hapsari et al., 2018; Noviyana, 2017). By involving students directly can increase student participation. This project-based learning model is also very influential on increasing student learning (Guo et al., 2020; Inthachot et al., 2013). HOTS activities also accompany E-LKPD development. HOTS activities are an important element in education because of their benefits in improving student achievement, reducing weaknesses, interpreting, synthesizing, solving problems, and controlling information, ideas, and daily activities (Jarvis \& Baloyi, 2020; Yijing et al., 2020). HOTS is a skill that students can broadly apply concepts and analyze concepts and analyze concepts (Ahmad et al., 2018; Fanani, A., \& Kusmaharti, 2014). These higher-order thinking skills include critical thinking, problem planning, creativity, innovation, communication, collaboration, confidence, argumentative and decision-making abilities (Antara et al., 2020; Niswara et al., 2019). The media that can be developed was project-based learning-based E-LKPD with HOTS activities on the material volume of cubes and blocks whose validity was tested.

\section{METHOD}

This research was conducted to develop E-LKPD in mathematics lessons on the volume of cubes and blocks. The development activities were carried out using a 4-D model. 4-D model developed by Thiagrajan (Purnama et al., 2017). This model consists of four stages, Define, Design, Develop, and Disseminate. Due to the current situation during the Covid-19 pandemic, the fourth stage was not carried out. The following is an explanation of the four stages. The first step, Defne, consists of five main activities, front-end analysis, analyzing the basic competencies of mathematics lessons in fifth grade in the second semester, and analyzing the learning media used by teachers. Student analysis, characteristic analysis was conducted to determine students' background knowledge, academic ability, cognitive development, and students' families' economic factors. Task analysis was carried out by analyzing the basic competency standards in the fifth-grade elementary school mathematics material in the second semester to provide assignments following the material to be taught. Concept analysis aims to determine the content of the material in the developed media. Concept analysis was made in the learning concept map, which will be used to achieve certain competencies by identifying and systematically compiling the main parts of the learning material. Specification of objectives, this stage is carried out to formulate the results of the previous material analysis that has been carried out. These indicators will then become the learning objectives to be achieved by students and, simultaneously, to prepare practice questions at the HOTS level. The second step is the design of the teaching materials that will be developed. The planning stage was carried out after the analysis stage is complete. The design begins with making an overall media design that includes cover design and each page design, specifying each page's material and material sections. In the process of designing this E-LKPD using Microsoft Word, Canva, PicsArt, and Fipbuilder. After the design was completed, consultations were carried out with the supervisor to get input and suggestions. Based on input and suggestions from the supervisor, improvements were made and continued to the development stage. In addition to designing the researchers, they also compiled a questionnaire that will test the validity of the developed. Questionnaires compiled will be given to content experts in mathematics, learning media experts, and practitioners.

The third step was developing teaching materials. After the media has been developed, the validity of the media was tested by giving assessment sheets to media experts, content experts, and practitioners. It was done to determine the validity of the developed media. The validity test was carried out by giving assessment sheets to content experts, media experts, and practitioners consisting of four lecturers and two teachers. A valid instrument is needed o test the validity of the E-LKPD. The instrument that can test the validity of the product is in the form of a questionnaire. After designing the instrument, it was tested for the validity of the contents by two lecturers who are competent in their field. The validity of the tested questionnaires were 1) subject content experts, 2) learning media experts, 3) practitioners.

The subjects in this study were two lecturers who are content experts, two lecturers of media experts, and two practitioners. A content validity test of the instrument was conducted by two lecturers 
who are competent in their fields to test the effectiveness of the E-LKPD. Data collection in this study used a questionnaire/questionnaire method. The instrument used in collecting research data is in the form of a rating scale. A rating scale is a measure of a subject that is scaled. The scoring step is to put a checkmark in the column with a score range of 1-5. This questionnaire was also expected to write suggestions, input, or comments to reference revision. In this development research, data analysis carried out using two data analysis techniques: qualitative descriptive analysis techniques and quantitative descriptive analysis. The descriptive analysis method is a way of analyzing or processing data by systematically compiling in the form of sentences/words, categories regarding objects so that finally general conclusions are obtained. The instrument grid can be seen in Table 1, Table 2, and Table 3.

Table 1. Material Content Expert Instruments

\begin{tabular}{cll}
\hline No. & Aspect & Indicator \\
\hline 1 & Contents & Compatibility with KD \\
& & Clarity of Purpose \\
& Suitability to student needs \\
& The truth of material substance \\
& & Image illustration suitability \\
& & Readability \\
& clarity of information \\
& Compliance with the rules of Indonesian \\
& Language & Use language effectively and efficiently \\
& & completeness of information \\
& & Giving motivation
\end{tabular}

Table 2. Instruments of learning media experts

\begin{tabular}{|c|c|c|}
\hline No. & Aspect & Indicator \\
\hline \multirow{4}{*}{1} & Screen design display & Composition of text color with background (background) \\
\hline & & Layout \\
\hline & & Title clarity \\
\hline & & Design attractiveness \\
\hline 2 & Ease of use & Ease of use \\
\hline \multirow{2}{*}{3} & Benefits & Ease of teaching and learning activities \\
\hline & & Attracts students' attention \\
\hline \multirow{3}{*}{4} & Graphics & Use of color \\
\hline & & Use of letters \\
\hline & & Use of illustrations \\
\hline
\end{tabular}

Table 3. Practitioner's Instrument

\begin{tabular}{cll}
\hline No. & Aspect & Indicator \\
\hline 1 & Content eligibility & Compatibility with KD \\
& & Purpose fit \\
& Systematic presentation \\
& & Complete information \\
& & The truth of material substance \\
& & Readability \\
& Language & clarity of information \\
2 & & Language use \\
& & Ease of learning \\
3 & Benefits & Ease of use of E-LKPD \\
& & Use of letters \\
& Graphics & Using illustrations, graphics, and pictures \\
\hline
\end{tabular}

This data analysis technique is carried out by grouping information from qualitative data in input, feedback, criticism, and suggestions for improvement in the questionnaire from distributing questionnaires at the beginning of the study. The results of the analysis were used to revise the developed product. The quantitative descriptive analysis method is a method of data processing that systematically compiles numbers and percentages regarding an object under study to obtain general conclusions. This analysis technique was used to process the data obtained through a questionnaire in a descriptive 
percentage. To be able to make decisions, the provisions are presented in Table 4 . The test results were calculated using the Gregory formula to determine the coefficient of content validity. The results of the validity test were entered in the $2 \times 2$ cross-tabulation. The coefficient of content validity can be calculated using the Gregory formula.

Table 4. Achievement level on a scale of five

\begin{tabular}{ccc}
\hline Achievement Level (\%) & Qualification & Description \\
\hline $90-100$ & Very good & No need to revise \\
$75-89$ & Good & Slightly revised \\
$65-79$ & Enough & Revised sufficiently \\
$55-64$ & Less & Many things are revised \\
$1-54$ & Bad & Repeated made products \\
\hline
\end{tabular}

\section{RESULT AND DISCUSSION}

\section{Result}

The development model used is a 4-D model consisting of Define, Design, Develop, and Disseminate. Based on these stages, which in this study only reached the development stage, the results obtained in E-LKPD media on the material volume of cubes and blocks for fifth-grade elementary school were already valid. In this research, the definition stage defines and defines learning needs by analyzing the objectives and limitations of the material. This study began distributing questionnaires to teachers in SD Gugus IV, Kecamatan Buleleng to collect information related to mathematics and media use in learning mathematics. Front-end analysis was done by analyzing the syllabus of even semester mathematics lessons. Based on the results of the questionnaire that has been given to the teacher, it can be seen that in the process of learning mathematics, the teacher has not used learning media, especially in mathematics. Learning was done by the teacher explaining to the students, and then the students are given practice questions. The learning resources used by students are limited to textbooks and worksheets, so students are less than optimal in understanding the concepts of the material. Therefore, innovations are needed to overcome this. These innovations can improve students' thinking power in understanding concepts, especially in the material for the volume of cubes and blocks for fifth-grade elementary school. The analysis of student characteristics indicates that elementary school students are at the stage of concrete operational development, as are fifth graders of SD Gugus IV, Kecamatan Buleleng. Concept analysis aims to identify, detail, and systematically compile relevant concepts to be taught based on front-end analysis. The concept is in the form of volume of cubes and volume of blocks in fifth-grade elementary school. It was obtained from the results of the syllabus analysis that has been carried out. In this step, the researcher analyzes the tasks in the form of competencies developed in the learning process. This activity was intended to identify the skills possessed by students that will be developed in learning. Based on student analysis and analysis of the concept of the cube and a cuboid volume, the tasks performed to find the formula of cube volume, calculate the volume of a cube, find the formula for the volume of a cube, and calculate the volume of a cube. The specification of learning objectives is carried out by formulating the task analysis results and analyzing the above concepts to achieve learning outcomes. The details of the learning objectives are as follows; after working on the E-LKPD, students can find out how to find the formula for the volume of a cube correctly. After working on the E-LKPD, students can calculate the volume of the cube correctly. After working on the E-LKPD, students can find out how to find the formula for the volume of a cube correctly. After doing the E-LKPD, students can calculate the volume of the block correctly.

The Design phase was carried out after the analysis phase is complete. The design begins with making the overall media design, including cover design and each page design, specifying each page's material and material sections. After the design was completed, the supervisor carried out consultations to get input and suggestions on the design. Based on input and suggestions from the supervisor, improvements were made and continued to the development stage. In addition to designing, the researchers also compiled a questionnaire that will test the validity of the developed media. The compiled questionnaire will be given to mathematicians, learning media experts, and practitioners.

According to the design and input from the supervising lecturer, at the Development stage, the ELKPD media was compiled on the material of volumetric buildings, cubes, and blocks for the fifth grade of elementary school. The material contained in the E-LKPD is following the basic competencies contained in the even semester maths syllabus. The stages of activities are adjusted to HOTS activities, analyzing (C4) by giving problems in the E-LKPD. Evaluating (C5) through students filling out answers related to problems that have been analyzed by students Creating (C6) is described by students doing activities to 
make aquariums according to their opinion Anderson, Krathwohl, \& Bloom, (2001). Students can express their creativity. It will make students more active in participating in the learning process. The results of the development can be seen as follows.

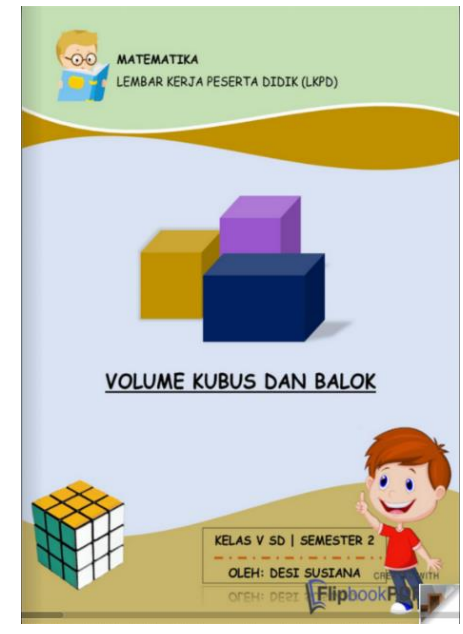

(a) Cover

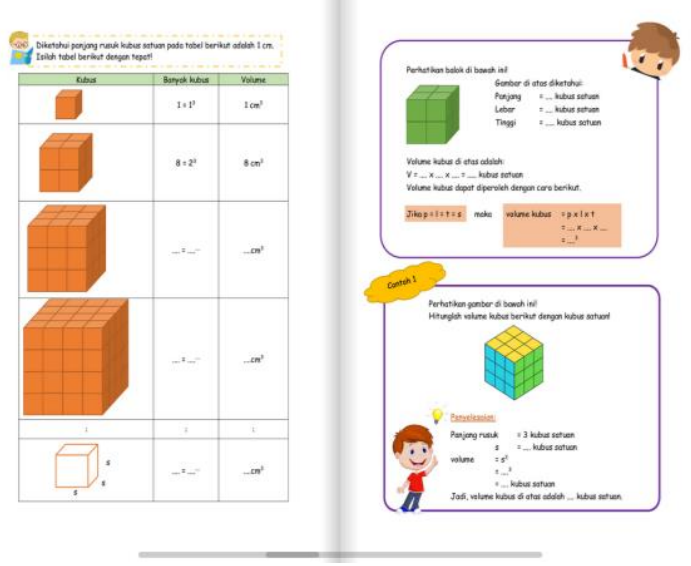

(c) Material of E-LKPD

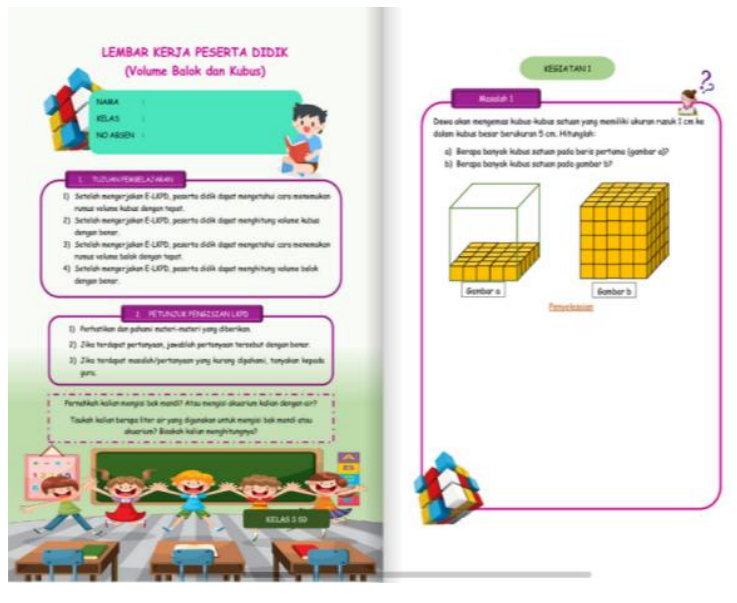

(b) Instructions for using E-LKPD

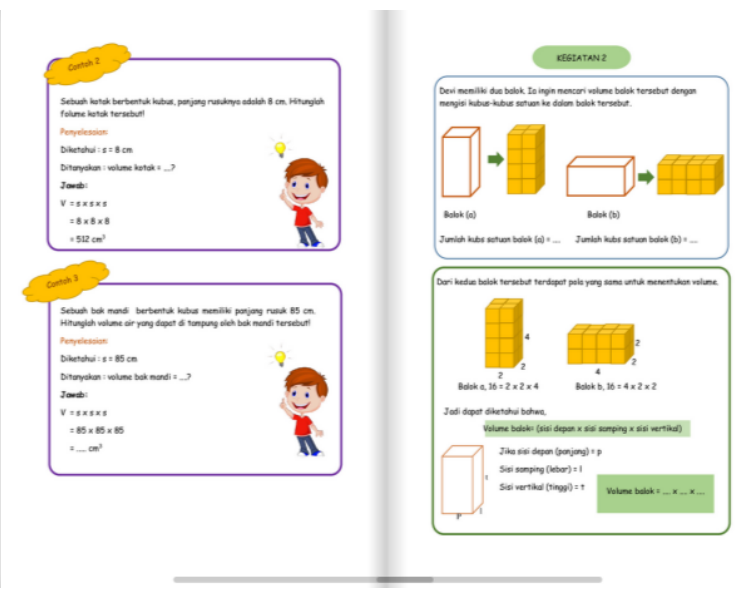

(d) Sample questions and solutions

Figure 1. E-LKPD mathematics on the material volume of cubes and blocks

After the media has been developed, the validity of the media was tested by giving assessment sheets to content experts, media experts, and practitioners. It was done to determine the validity of the developed media. The validity test was carried out by giving assessment sheets to content experts, media experts, and practitioners consisting of four lecturers and two teachers. The validity of the E-LKPD obtained from experts is presented in Tables $5,6,7$. Table 05 shows the validity of the two material experts is $85 \%$, which, when viewed from the table of achievement on a scale of five, means that the validity of the E-LKPD is based on project-based learning of cube and block volume material is in good qualification. Table 06 shows the validity of the two media experts, respectively, $94.29 \%$ and $84.29 \%$, with an average percentage of $89.29 \%$. If the convention is in the level of achievement on a scale of five, it means that the validity results based on project-based learning material for the volume of cubes and blocks are in good qualification. Table 07 shows the validity of the two practitioners, respectively, $97.5 \%$ and $77.5 \%$, with an average percentage of $87.5 \%$. If it is convened in the level of achievement of a scale of five, it means that the results of product validity are in good qualification.

Table 5. Results of the Validity Analysis of the Material Expert Test

\begin{tabular}{clcc}
\hline No & Validator & Validity Results (\%) & Description \\
\hline 1 & First Material Expert Test & 85 & Good \\
2 & Second Material Expert Test & 85 & Good \\
\hline
\end{tabular}


Table 6. The results of the analysis of the validity of the media expert test

\begin{tabular}{cccc}
\hline No & Validator & Validity Results (\%) & Description \\
\hline 1 & First Material Expert Test & 94,29 & Good \\
2 & Second Material Expert Test & 84,29 & Good \\
\hline Average & & 89,29 & Good \\
\hline
\end{tabular}

Table 7. Results of practitioner test validation analysis

\begin{tabular}{cccc}
\hline No & Validator & Validity Results (\%) & Description \\
\hline 1 & First Practitioner Test & 97,5 & Good \\
2 & Second Practitioner Test & 77,5 & Good \\
\hline Average & & $\mathbf{8 7 , 5}$ & Good \\
\hline
\end{tabular}

\section{Discussion}

The development of project-based learning-based E-LKPD with HOTS activities in mathematics lessons on the volume of cubes and blocks received good qualifications in all aspects of the assessment. Judging from assessing the suitability of objectives with the material presented by E-LKPD, it follows the learning objectives in the 2013 curriculum. The formulation of objectives in learning is very important to note. Goals are one of the most important learning activities (Emda, 2018; Pane, 2017). The review opinion from the aspect of the material content has good qualifications because the presentation of the material follows the demands of the core competencies, basic competencies, syllabus, and lesson plans used. The suitability of content with learning objectives is very important in making media. It is in line with expert opinion that it is necessary to pay attention to learning objectives, basic competencies, and indicators in assessing content aspects. Good learning comes from a clear goal. Clear goals will be a reference in every learning process that takes place and preferably. This learning media in the form of ELKPD gets good qualifications because this E-LKPD has the advantage of higher-order thinking skills activities. This HOTS activity follows Bloom's Taxonomy indicators, which contain problem-solving skills, creative thinking skills, critical thinking, argumentation skills, and decision-making abilities.

Learning that applies HOTS activities will make students think creatively and critically about a problem. This HOTS activity is said to be very in line with the expectations of the 2013 curriculum, active student-oriented learning so that students have the opportunity to observe, ask questions, reason, try, and communicate (Fanani, A., \& Kusmaharti, 2014; Pratiwi, 2019). In addition, the use of the project-based learning model is one of the reasons the E-LKPD media gets good qualifications. The project-based learning model can make students more active in solving complex problems with real products (Dwiantoro \& Basuki, 2021; Wahyu et al., 2018). Based on the input, comments, and suggestions of material content experts, revised suggestions at the end of the E-LKPD are filled with a conclusion column to clarify the subject matter. The final summary reviews the main points made then remembering the points in the text (Sudarma et al., 2015). Thus it can be concluded that at the end of each activity, it is necessary to add a conclusion column to emphasize the concepts that have been studied.

Long and abstract descriptions are easier to understand when compared to words (Hastari et al., 2019; Sudarma et al., 2015). Images will also make it easier for people to remember messages or materials presented in one medium. Images included in a message or material presented in a media. Messages conveyed with images make it easier to understand a concept not to be misperceived and easy to remember. In line with this, the developed E-LKPD contains images relevant to the material and messages conveyed to the E-LKPD. Later, students will not confuse in learning to use the E-LKPD. This good quality of E-LKPD was obtained because the developed E-LKPD media has taken into account the principles of message design, one of which is the presentation of the text. Message design is important to note because it will make it easier for students to understand the material. That the text is designed based on message design theories will provide a lot of information. Vice versa, if the presentation of the text does not pay attention to the principles of message design, it will tend to make it difficult for students to understand it (Hardianto, 2011; Sudarma et al., 2015). The presentation in this E-LKPD uses the comic san font type, which is 12 point font size, san serif typeface and the font size has a high readability level, and good font size is not less than 10 points so that it is easily understood by students (Kresno, 2013; Sudarma et al., 2015).

Based on the input, comments, and suggestions of learning media experts, some suggestions are revised. The revision was carried out on the cover of the E-LKPD, which initially contained the student's 
identity, how to use it, and the learning objectives were replaced with a cover containing the identity of the E-LKPD. The communication process delivers messages from the source of the message through certain channels or media to the message's recipient (Sudarma et al., 2015; Syatriadin, 2018). From this opinion, it can be concluded that the channel or media can convey a message to the recipient of the message. The E-LKPD cover was made to provide an overview of the contents of the E-LKPD to the reader. In addition, there is an inappropriate use of color in one part. There are several principles in choosing a combination of text and background colors in making media: (1) if the background color is dark, then the text color is light. If the background color is light, then the text is dark. (2) the background must be simple, not graphic, and usually must have only one color. (3) if the background uses two colors, keep one close to the color wheel. (4 ) gray color is avoided, both in text and background (Sitepu, 2006; Sudarma et al., 2015). Words that are often used in everyday life for elementary school children. This E-LKPD was also equipped with pictures that can make it easier for students to understand the material. The suitability of image descriptions with images greatly affects the clarity of a message conveyed in a medium. One of the principles of designing images in a medium is to provide clear instructions or information to interpret so that there is no misperception. Based on practitioners' input, comments, and suggestions, some suggestions are revised to present sample questions and solutions. It needs to be added so that students can better understand the material.

E-LKPD is in good qualification also because of the HOTS activities used. HOTS-based learning is learning that develops critical thinking skills. Developing critical thinking requires practice finding patterns, constructing explanations, making hypotheses, generalizing, and documenting findings with evidence. The provision of problems that exist in the E-LKPD media is also following the problems that exist in students' daily lives by giving important problem-solving questions given to students. One of the reasons is that students are invited to be able to know problem-solving procedures, be able to make analysis and synthesis, and are required to evaluate the results of the solution (Mulyati, 2016; Wahyu et al. 2018). Thus students will have high curiosity, motivate and make students think more actively.

The mathematical e-LKPD for the volume of cubes and blocks has also been developed following technological developments. This development is innovation. By uniting the skills of analyzing, evaluating, and creating in online E-LKPD, it becomes more practical. The use of technology in education is very useful to support academic learning anywhere and anytime. The more technology used, the more efficient it will be and can achieve maximum value. In line with the opinion, Khotimah states that the use of E-LKPD in the learning process reaches $100 \%$ in the assessment of learning completeness. E-LKPD is suitable for elementary school students because material experts very well qualify it, media experts, teachers, and students (Apriyanto et al., 2019; Ulfa et al., 2020). From the results of similar research, the E-LKPD media for the volume of cubes and blocks was believed to be good and feasible for the learning process. The development of this E-LKPD can help teachers and students in the learning process both from home and at school. This E-LKPD will make students directly involved in learning so that learning will be more meaningful. This development research was only carried out until the development stage, which resulted in product validity. At the same time, its practicality and effectiveness were not investigated due to the current state of the Covid-19 pandemic. For this reason, it is hoped that other researchers can continue this research at the development stage through experimental research.

\section{CONCLUSION}

The E-LKPD media in mathematics subjects with the volume of cubes and blocks developed with the 4-D model as a whole has been valid with good qualifications. The content in the E-LKPD can make students more active and creative in carrying out learning, both learning from home and learning at school.

\section{REFERENCES}

Agung, A. A. . (2014). Metodologi Penelitian Pendidikan. Aditya Media Publishing.

Ahmad, S., Kenedi, A. K., \& Masniladevi, M. (2018). Instrumen Hots Matematika Bagi Mahasiswa Pgsd. JURNAL PAJAR (Pendidikan Dan Pengajaran), 2(6), 905. https://doi.org/10.33578/pjr.v2i6.6530.

Al Farisyi, S., Syafe'i, I., \& Dinda Pratiwi, D. (2016). Modul Elektronik Matematika Berpendekatan Contextual Teaching Learning untuk Peserta Didik MTS kelas VII. Prosiding Seminar Nasional Matematika Dan Pendidikan Matematika UIN Raden Intan Lampung, 423-431.

Amir, A. (2014). Pembelajaran Matematika SD dengan Menggunakan Media Manipulatif. Forum Paedagogik, 06(01), 72-89.

Anderson, L. W., Krathwohl, D. R., \& Bloom, B. S. (2001). A taxonomy for learning, teaching, and assessing: a 
revision of Bloom's taxonomy of educational objectives. 41(4), 352.

Antara, I. G. W. S., Sudarma, I. K., \& Dibia, I. K. (2020). The Assessment Instrument of Mathematics Learning Outcomes Based on HOTS Toward Two-Dimensional Geometry Topic. Indonesian Journal Of Educational Research and Review, 3(1), 19. https://doi.org/10.23887/ijerr.v3i2.25869.

Apriyanto, C., Yusnelti, \& Asrial. (2019). Development of E-LKPD with Scientific Approach of Electrolyte and Non-ElectrolyteSolutions. Journal of Indonesian Society of Integrated Chemistry, 11(1), 38-42.

Dwiantoro, A., \& Basuki, I. (2021). Analisis Pengaruh Model Pembelajaran Project Based Learning Terhadap Peningkatan Hasil Belajar Siswa Pada Mata Pelajaran Instalasi Penerangan Listrik Di Smk. Pendidikan Teknik Elektro, 10, 81-88.

Dwiranata, D., Pramita, D., \& Syaharuddin, S. (2019). Pengembangan Media Pembelajaran Matematika Interaktif Berbasis Android Pada Materi Dimensi Tiga Kelas X SMA. Jurnal Varian, 3(1), 1-5. https://doi.org/10.30812/varian.v3i1.487.

Emda, A. (2018). Kedudukan Motivasi Belajar Siswa Dalam Pembelajaran. Lantanida Journal, 5(2), 172. https://doi.org/10.22373/lj.v5i2.2838.

Fanani, A., \& Kusmaharti, D. (2014). Pengembangan Pembelajaran Berbasis HOTS (Higher Order Thinking Skill) di Sekolah Dasar Kelas V. Jurnal Penndidikan Dasar, 1(9), 1-11.

Guo, P., Saab, N., Post, L. S., \& Admiraal, W. (2020). A review of project-based learning in higher education: Student outcomes and measures. International Journal of Educational Research, 102(April), 101586. https://doi.org/10.1016/j.ijer.2020.101586.

Handayani, E. S. (2017). Pengaruh Model Pembelajaran Kooperatif Tipe Number Heads Together (NHT) Terhadap Hasil Belajar Sejarah. Jurnal Pendidikan Sejarah, 5(2), 16. https://doi.org/10.21009/jps.052.02.

Hapsari, D. I., Airlanda, G. S., Profesi, P., Universitas, G., \& Satya, K. (2018). Penerapan Project Based Learning Untuk Meningkatkan Motivasi Belajar Matematika Peserta Didik Kelas V Implementation of Project Based Learnng To Improve Mathematics Learning Motivation the. Jurnal Pendidikan Dasar Islam, 5(2), 154-161.

Hardianto, D. (2011). Penerapan Prinsip Desain Multimedia Untuk Pembelajaran. International Conference Proceeding "ICT in Education For Peace," 1, 3.

Hastari, G. A. W., Agung, A. A. G., \& Sudarma, I. K. (2019). Pengembangan Modul Elektronik Berpendekatan Kontekstual Pada Mata Pelajaran Ilmu Pengetahuan Sosial Kelas Viii Sekolah Menengah Pertama. EDUTECH Universitas Pendidikan Ganesha, 7, 33-43.

Indaryati, I., \& Jailani, J. (2015). Pengembangan Media Komik Pembelajaran Matematika Meningkatkan Motivasi Dan Prestasi Belajar Siswa Kelas V. Jurnal Prima Edukasia, 3(1), 84-96. https://doi.org/10.21831/jpe.v3i1.4067.

Inthachot, M., Sopeerak, S., \& Rapai, N. (2013). The Development of a U-learning Instructional Model Using Project based Learning Approach to Enhance Students' Creating-innovation Skills. Procedia Social and Behavioral Sciences, 103,1011-1015. https://doi.org/10.1016/j.sbspro.2013.10.426.

Jarvis, M. A., \& Baloyi, O. B. (2020). Scaffolding in reflective journaling: A means to develop higher order thinking skills in undergraduate learners. International Journal of Africa Nursing Sciences, 12(October 2019), 100195. https://doi.org/10.1016/j.ijans.2020.100195.

Kamarullah, K. (2017). Pendidikan Matematika Di Sekolah Kita. Al Khawarizmi: Jurnal Pendidikan Dan Pembelajaran Matematika, 1(1), 21. https://doi.org/10.22373/jppm.v1i1.1729.

Khotimah, S. K. (2020). Pengembangan E-LKPD Matematika Berbasis Penguatan Pendidikan Karakter (PPK) Kelas V SD. Pengembangan E-LKPD Matematika Berbasis Penguatan Pendidikan Karakter (PPK) Kelas V SD, 4, 407.

Kresno, Y. R. (2013). LKP: Pembuatan Buku Company Profile PT. Karya Jaya Lestari sebagai Media Operasional dan Inventaris Perusahaan. STIKOM Surabaya.

Masykur, R., Nofrizal, N., \& Syazali, M. (2017). Pengembangan Media Pembelajaran Matematika dengan Macromedia Flash. Al-Jabar: Jurnal Pendidikan Matematika, 8(2), 177. https://doi.org/10.24042/ajpm.v8i2.2014.

Muhson, A. (2010). Pengembangan Media Pembelajaran Berbasis Teknologi Informasi. Jurnal Pendidikan Akuntansi Indonesia, 8(2). https://doi.org/10.21831/jpai.v8i2.949.

Mulyati, T. (2016). Kemampuan Pemecahan Masalah Matematis Siswa Sekolah Dasar (Mathematical Problem Solving Ability of Elementary School Students). EDUHUMANIORA: Jurnal Pendidikan Dasar, 3(2), 1-20.

Niswara, R., Fita, M., \& Untari, A. (2019). Pengaruh Model Project Based Learning Terhadap High Order Thinking Skill. Mimbar PGSD Undiksha, 7(2), 85-90.

Noviyana, H. (2017). Pengaruh Model Project Based Learning Terhadap Kemampuan Berpikir Kreatif Matematika Siswa. JURNAL E-DuMath, 3(2). https://doi.org/10.26638/je.455.2064. 
Nurita, T. (2019). Development of circle learning media to improve student learning outcomes. Journal of Physics: Conference Series, 1321(2), 171-187. https://doi.org/10.1088/17426596/1321/2/022099.

Pane, A. (2017). Belajar dan Pembelajaran Aprida Pane Muhammad Darwis Dasopang. Fitrah, 03(2), 333352.

Pansa, H. E. (2017). Pengembangan Lkpd Dengan Model Problem Based Learning ( Pbl ) Untuk Meningkatkan Kemampuan. Seminar Nasional Matematika Dan Pendidikan Matematika 2017, 229-238.

Pratiwi, W. (2019). Optimalisasi Pendekatan Saintifik Dengan Pembelajaran Inkuiri Untuk Meningkatkan Kemampuan Berpikir Kritis Di Madrasah Ibtidaiyah. INSANIA: Jurnal Pemikiran Alternatif Kependidikan, 23(2), 174-191. https: //doi.org/10.24090/insania.v23i2.2289.

Purnama, M. D., Irawan, E. B., \& Sa'dijah, C. (2017). Pengembangan Media Box Mengenal Bilangan Dan Operasinya Bagi Siswa Kelas 1 di SDN Gadang 1 Kota Malang. Jurnal Kajian Pembelajaran Matematika, 1(1), 46-51.

Puspita, V., \& Dewi, I. P. (2021). Efektifitas E-LKPD berbasis Pendekatan Investigasi terhadap Kemampuan Berfikir Kritis Siswa Sekolah Dasar. Jurnal Cendekia : Jurnal Pendidikan Matematika, 5(1), 86-96. https://doi.org/10.31004/cendekia.v5i1.456.

Saefudin, A. A. (2012). Pengembangan Kemampuan Berpikir Kreatif Siswa Dalam Pembelajaran Matematika Dengan Pendekatan Pendidikan Matematika Realistik Indonesia (PMRI). Al-Bidayah, 4(1), 37-48.

Sari, F. N., Nurhayati, \& Soetopo, S. (2017). Pengembangan Lembar Kerja Peserta Didik (LKPD) Elektronik Teks Cerita Pendek Berbasis Budaya Lokal. Seminar Nasional Pendidikan Bahasa Indonesia, 1, 8398.

Sitepu, V. (2006). Panduan mengenal desain grafis. Diambil Dari Http://Www. Belajargrafis. Imywebsit.

Suartama, I. K. (2010). Kualitas Pembelajaran Pada Mata Kuliah Media. Jurnal Pendidikan Dan Pengajaran, 43(3), 253-262.

Sudarma, I. K., Teguh, I. M., \& Prabawa, D. G. A. P. (2015). Desain Pesan Kajian Analitis Desain Visual Teks dan Image. Yogyakarta: Graha Ilmu.

Syatriadin. (2018). N u a $\mathrm{n}$ a. 2018, 23-32.

Tafonao, T. (2018). Peranan Media Pembelajaran Dalam Meningkatkan Minat Belajar Mahasiswa. Jurnal Komunikasi Pendidikan, 2(2), 103. https://doi.org/10.32585/jkp.v2i2.113.

Ulfa, I., Rahayu Sesanti, N., \& Yulianti. (2020). Pengembangan E-LKPD dengan Pendekatan Contextual Teaching and Learning (CTL) pada Materi Pecahan di kelas IV MI Azharul Ulum Sukodono Dampit. Journal of Chemical Information and Modeling, 53(9), 1689-1699.

Wahyu, R., Islam, U., \& Rahmat, R. (2018). Implementasi Model Project Based Learning ( PJBL ) Ditinjau dari Penerapan Implementasi Model Project Based Learning ( PJBL ) Ditinjau dari Penerapan Kurikulum 2013. Teknoscienza, 1(1), 50-62.

Widyastuti, N. S., \& Pujiastuti, P. (2014). Pengaruh Pendidikan Matematika Realistik Indonesia (Pmri) Terhadap Pemahaman Konsep Dan Berpikir Logis Siswa. Jurnal Prima Edukasia, 2(2), 183. https://doi.org/10.21831/jpe.v2i2.2718.

Yijing, L., Su, Y., Lin, Y., He, L., Wu, L., Hou, X., \& Zheng, C. (2020). Jo ur I P re of. Building and Environment, 184(August), 107229. https://doi.org/10.1016/j.heliyon.2021.e07309.

Zakiy, M. A. Z., Muhammad, S., \& Farida. (2018). Pengembangan Media Android dalam Pembelajaran Matematika. TRIPLE S:Jourals of Mathematics Education, 1(2), 87-96. 